Vol. 38(2), pp. 230-244, Dec. 2019

ISSN 1821-536X (print)

ISSN 2619-8789 (electronic)
Tanzania Journal of Engineering and Technology

Copyright (C) 2019 College of Engineering and

Technology, University of Dar es Salaam

Review Paper

\title{
The Potentials of Faecal Sludge Treatment using Local Conditioners in Tanzania: A Review
}

\author{
Benjamin Doglas $^{*}$, Aloyce W. Mayo ${ }^{1}$, Sara Gabrielsson ${ }^{2}$ and Richard Kimwaga ${ }^{1}$ \\ ${ }^{1}$ Department of Water Resources Engineering, College of Engineering and Technology, University \\ of Dar es Salaam, P. O. Box 35131, Tanzania \\ ${ }^{2}$ Lund University Centre for Sustainability Studies (LUCSUS), Lund University, Sweden \\ *Corresponding author: benjamindoglas@gmail.com
}

\begin{abstract}
Worldwide, every day human beings generate millions of tons of Faecal Sludge (FS), which is rich in water, nutrients, energy, and organic compounds. Yet FS is not being managed in a way that permits us to derive value from its reuse, while at the same time, millions of farmers struggle with depleted soils and lack of water. In most of the developing countries, energy for cooking is mainly derived from cutting of trees, either as wood or charcoal. Resource recovery and reuse from FS can create livelihoods, enhance food security, support green economies, reduce waste and contribute to cost recovery in the sanitation chain. Many studies have reported on the different technologies used for FS treatment, such as dewatering and bio-stabilization. The commonly used dewatering technology is sand drying bed, which occupied a large space and has a low dewatering rate. To enhance the dewatering rate of FS as well as reducing the size of the sand drying bed, the use of chemical conditioners has been done. Despite the fact that they have been used successfully, chemical conditioners are expensive, have health and environmentally hazardous. In recent years, attempts have been made to use local conditioners to tackle the drawbacks experienced from chemical conditioners. Although the feasibility of applying local conditioners for FS dewatering has been studied, its potentials on FS treatment have not been well documented. This review indicates that there is potential for local conditioners linked with dewatering, enhancing of FS resources recovery and in reducing costs of operating and maintaining FS treatment plant. Moreover, local conditioners have the potential in contribution to socio-economic development in Tanzania through renewable energy production, income generation and food-health security, soil and water conservation, eco-sanitation and reduction of environmental degradation.
\end{abstract}

Keywords: Faecal sludge, Local conditioners, Resource recovery, Sanitation, Treatment.

\section{INTRODUCTION}

Improved sanitation has significant impacts not only on health, but on social and economic development. In Sub-Saharan African countries, over $80 \%$ of the population relies on on-site sanitation systems (Chase and Hutton, 2016), which are likely to remain dominant in the near future due to massive rural-urban migration, economic inequality and high capital costs of sewer system (Cockx et al., 2019). One of the challenges to use on-site sanitation systems is the management of accumulating faecal sludge (FS). This challenge is due to its complex mixture of human excreta, water, solid waste, pathogens and nutrients, which are dangerous to both human health and the environment (Cross and Coombes, 2014). However, if FS is managed safely, it can be recovered and used for energy 
and for agricultural purposes and thus, contribute to the community income.

Over $90 \%$ of $\mathrm{FS}$ is a liquid which poses difficulties not only in transportation, but also in treatment and resource recovery. This means, removing water from FS is the most important process. The most common methods for removing bonded water from FS are mechanical and physical systems such as belt filter presses and sand drying beds (Dodane et al., 2012). These systems have many drawbacks as they are expensive, consume high amounts of energy, land intensive and timeconsuming (Shikun et al., 2017). In the recent years, research on the application of local conditioners has generated the interest of many researchers in an attempt to address the drawbacks of mechanical and physical systems.

The world is increasingly experiencing resources crisis in recent years (Alloul et al., 2018). Resource recovery from FS such as biogas, fire briquettes and soil conditioners are increasingly gaining interest of many researchers (Abdulazeez et al., 2015). These researchers have focused only on its yield, health hazard, technical aspect for collection and storage of these resources, but little has been done in low cost resources recovery (Kansal and Kumari, 2014). Local conditioners have been reported to enhance low cost resource recovery from FS, but a review of its potential and constraints has not been summarized (Abdulazeez et al., 2015). The purpose of this paper is to review the potential of locally available conditioners in view of recovering resources from FS and describe the ways Tanzania can benefit on these potentials in solving some emerging challenges. In particular, this study reviews application of local conditioners on treatment and resource recovery from $\mathrm{FS}$, reducing the cost of construction, operation and maintenance of the sanitation structures.

\section{CLASSIFICATION AND PROPERTIES OF LOCAL CONDITIONERS}

Conditioners are skeleton builder aids which are used to improve the compressibility of sludge, the mechanical strength and permeability of solids existing in sludge during compression (Zhang et al., 2019a). According to Gold et al. (2016), conditioners can generally be categorized as conventional conditioners and locally available conditioners. Conventional conditioners are produced in industries while locally available conditioners are naturally obtained from either plant, animal or waste material in domestic and agricultural waste (Jin et al., 2004). They can also be grouped into organic and inorganic, natural and chemical conditioners (Semiyaga et al., 2017).

Treatment of wastewater and FS by conventional conditioners is used worldwide (Yuan et al., 2011). However, conventional conditioners have negative impacts on human health and the environment due to its excess ions in the soil (Ndabigengesere et al., 1995). Moreover, conventional conditioners are relatively costly for developing countries and would need to be imported (Wang et al., 2013). The use of local conditioners has been serving as an alternative solution to the challenges created by the application of conventional conditioners in sludge treatment. The main advantage of some local conditioners is that it's by-products are; non-toxic and biodegradable, they are environmentally and health friendly, and do not significantly affect $\mathrm{pH}$ and conductivity of the treated effluents (Liao et al., 2014).

Furthermore, local conditioners have antimicrobial activity upon pathogens. For example, Moringa oleifera contains $4(\boldsymbol{\alpha}-\mathrm{l}-$ Rhamnosyloxy) benzyl isothiocyanate and Benzyl isothiocyanate compounds, which work as antimicrobial agents and are very effective against several bacteria and fungi (Padla et al., 2012). Additionally, these conditioners have coagulation capacity which can agglomerates the smaller sludge particles into larger particles prior to dewatering of sludge (Ashmawy et al., 
2012). Local conditioners function by means of adsorption mechanism followed by charge neutralization with bridging effect on the sludge dewatering as shown in Figure 1. Local conditioners have been reported to have the advantage of reducing FS treatment cost by $50 \%$ because of less volume of sludge it produces (Gold et al., 2016). However, it has some disadvantages on FS treatment, which is connected with accumulations of pathogens and heavy metal in bio-solid and increasing organic matter of the treated supernatant (Qi $e t$ al., 2019). In accordance with Semiyaga et al. (2017), local conditioners available include physical conditioners, plant-based and animal conditioners. These are discussed in turn hereunder.

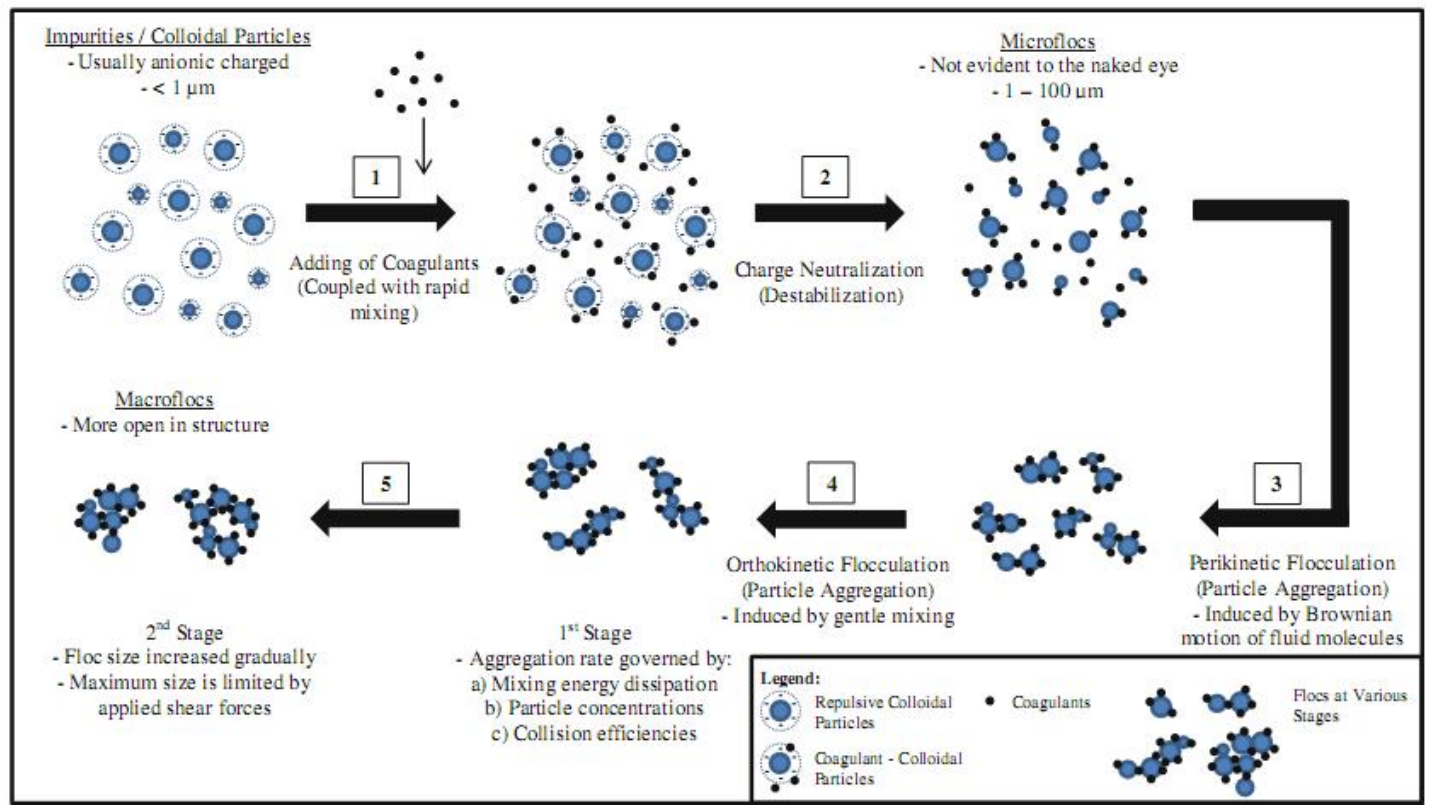

Figure 1: Neutralization of particles in sludge using local conditioners (Chony et al., 2015).

\section{Physical Conditioners}

These are either waste materials from domestic sources and/or agricultural by-products (Luo et al., 2013). The most common physical conditioners are: fly ash, lime and gypsum, wood chips and wheat dregs, rice shells and brans (Ding et al., 2014). Most of these conditioners are biodegradable and have carbon and nutrients contents, and thus, they are good for agriculture and energy resource (Semiyaga et al., 2017). However, most of physical conditioners have been associated with deforestation since some of them are derived from wood and they also affect the $\mathrm{pH}$ of treated effluents (Mittal et al., 2010).

These conditioners have an advantage of low moisture content comparable to that of FS (Byrne et al., 2015). Physical conditioners have been reported to improve the dewatering rate of FS through a permeable and the rigid structure formation (Diener et al., 2014). Moreover, some of these conditioners contain nutrients which are carbon-based and are biodegradable hence being good for both bio-energy and soil conditioner (Semiyaga et al., 2017; Lim et al., 2018).

\section{Animal-based Conditioners}

These conditioners originate from animal materials like fish. Some of the most commonly used animal-based coagulants include Isinglass from the shredded fish bladders and Chitosan from the shells of crustaceans (Biggs, 2007). These conditioners have in the last decade, received a great deal of attention in water treatment processes for the removal of particulates and dissolved 
contaminants (Gold et al., 2016). They have also, been used for enhancing the dewaterability rate of FS hence, its usefulness has been expanded in the field of wastewater and FS treatment (Ferguson et al., 2012; Gold et al., 2016). These are non-toxic and have high efficiency against pathogens, and thus, are used to recover valuable renewable resource products (Mukhopadhyay et al., 2018). Although, some disadvantages of animal-based conditioners are working effectively over a limited $\mathrm{pH}$ range and they destabilize particles dispersion in excess amount (Zhang et al., 2019b). Nonetheless, the quality of commercial availability is not uniform (Hanghighi et al., 2019; Ahmad et al., 2006).

\section{Plants-based Conditioners}

These conditioners originate from plant species, such as Moringa oleifera, Schoenoplectus tatora and Jatropha curcas. They are normally locally available and hence, are cost-effective (Lim, 2012). They also do not change the $\mathrm{pH}$ and conductivity of treated effluent (Ndabigengesere et al., 1995), are highly biodegradable (Yongabi, 2010), and therefore, are suitable for agriculture. Moreover, they contain nutrients and have antimicrobial activity on pathogens. They are therefore safe for both agriculture and human health (Ngandjui et al., 2018). However, plantbased conditioners have some disadvantage which is linked with increasing the COD of treated supernatant, and cannot be used alone for safe reuse of FS in agriculture (Lim, 2012; Yin, 2010). The availability of plant-based coagulants is much higher than animal-based conditioners, hence, they are potential alternatives to chemical coagulants (Yin, 2010).

\section{POTENTIAL OF LOCAL CONDITIONERS FOR FEACAL SLUDGE TREATMENT}

\section{Local Conditioner in Dewatering}

Bound water, in FS cannot be separated by conventional dewatering devices such as a centrifuge or compressor due to high strength bonding between water molecules and sludge solids surface (Zhai et al., 2012). Also, due to a low settleability rate of sludge colloidal particles, high compressibility of sludge solids (filterability) and high affinity of extracellular polymeric substances (EPS) lead to difficulties in dewatering of FS (Byrne et al., 2015). As a result of difficulties in dewatering, it leads to increase in the cost of treatment (Kolecka et al., 2017). Local conditioners contain protein, which has the ability to improve compressibility of sludge, the mechanical strength and permeability of solids existing in sludge during compression (Zhai et al., 2012). They therefore, improve the dewatering rate of FS and reduce the land required by centrifuge devices and sand beds. Gold et al. (2016) verified that, local conditioners improved the dewatering rate of FS at a range of $88-90 \%$ at optimum dosage of $0.3-0.6 \mathrm{ml} / \mathrm{g}$ TSS and reduces the required area of dying beds by 59$97 \%$ as compared to conventional conditioners (Table 1).

\section{Local Conditioner on Resource Recovery}

All FS treatment processes results in end products which are treated further, disposed of, or harnessed in some way for resource recovery. The potential use of end products should be considered from the initial design phase of any complete FS management system, as the treatment technologies used are intrinsically linked to the quality of end products generated (Chony et al., 2015). Apart from removing water in FS by local conditioners, it is also used for enhancing resource recovery; remove heavy metals, colour, as well as pathogens in FS (Abdulazeez et al., 2015). In recent years, there is an increasing number of studies reporting on the resource recovery value of FS (Alloul et al., 2018). Studies have focused mainly on its yield, improvement of the health hazard and technical aspect of collection and storage system, while the production of these resource products in affordable techniques remains marginal (Musparrt et al., 2014). This means, sanitation through local conditioners is 
essential for promoting health and resources

through recovering of resources.

Table 1: Efficiency of locally available conditioners as compared to conventional conditioners in settling and dewatering of faecal sludge (Gold et al., 2016).

\begin{tabular}{|l|c|c|c|}
\hline Parameter & Moringa Oleifera & Chitosan & Lime \\
\hline Concentration & $5 \%$ & $0.50 \%$ & \\
\hline Settling & $6-8 \mathrm{~mL} / \mathrm{GTS}$ & $0.3-0.6 \mathrm{ml} / \mathrm{g} \mathrm{TS}$ & $0.7-0.8 \mathrm{~g} / \mathrm{g} \mathrm{TS}$ \\
\hline Optimal dosage & $300-400 \mathrm{Kg} / \mathrm{t} \mathrm{TS}$ & $1.5-3.0 \mathrm{Kg} / \mathrm{tTS}$ & $700-800 \mathrm{~kg} / \mathrm{t} \mathrm{TS}$ \\
\hline TSS & $<0.2 \mathrm{~g} / \mathrm{L}$ & $<0.3 \mathrm{~g} / \mathrm{L}$ & $<0.2 \mathrm{~g} / \mathrm{l}$ \\
\hline TSS reduction & $81-95 \%$ & $88-90 \%$ & $83-88 \%$ \\
\hline Dewatering & $10 \mathrm{ml} / \mathrm{gTS}$ & $0.75 \mathrm{ml} / \mathrm{gTS}$ & $0.3 \mathrm{~g} / \mathrm{g} \mathrm{TS}$ \\
\hline Optimal dosage & $500 \mathrm{~kg} / \mathrm{tTS}$ & $3.75 \mathrm{~kg} / \mathrm{tTS}$ & $300 \mathrm{~kg} / \mathrm{t} \mathrm{TS}$ \\
\hline SRF reduction & $69-93 \%$ & $75-92 \%$ & $91-95 \%$ \\
\hline
\end{tabular}

\section{Local Conditioners for Energy Recovery}

Combined calorific values and sludge drying outcomes augur well for the technical and the financial viability of using FS as solid industrial fuel (Bennamoun, 2012). The dried FS has an average calorific value of 12-17 $\mathrm{MJ} / \mathrm{kg}$ at the end of the drying period, which is comparable to other commonly used biofuel (Muspratt et al., 2014), and an average ash content of $41.7 \%$ wet sludge (Seck et al., 2014). This calorific value is less than the calorific value of coal and charcoal, which is ranging between 26.7-36.7 $\mathrm{MJ} / \mathrm{kg}$ TS for energy use (Coal annual report, 2007). Another challenge that faces energy recovery from FS is the availability of enough FS dry solids when the project scaled up for industrial use. Predrying of the FS is an important requirement for fuel. For a net energy benefit, FS must be adequately dried to a minimum of $28 \%$ dry solids (Bennamoun, 2012). Even if technically viable, the commercial or large-scale viability of FS will be dependent upon the effective way of drying it. However, the existing drying systems have an ability of drying FS, but have the tendency to harness its energy if the effective drying time is reached (Cofie et al., 2006). Also, these systems are expensive, require large land, energy and time consuming (Gold et al., 2016). Drying systems are viable in the fuel production if the cost of drying FS to the point where net energy harnessed is less than the price that may be commended (Gold et al., 2014).

Several studies have tried to solve the challenges facing the existing systems by applying rapid prototyping polymer, but due to additional energy required to purchase the polymer, this initiative was unsuccessful (Muspratt et al., 2014). However, local conditioners are cheap since they are not required to be imported and transported and hence, have been used to overcome the drawbacks of prototyping polymer (Ferguson, 2012). Local conditioners serve as a starting point for exploring the use of FS as fuel and the potential for increasing drying rates while minimizing costs. Furthermore, local conditioners increase the calorific value of FS since it has a carbon-based of calorific value of 20-28 MJ/ kg, hence, makes FS to meet calorific value required by energy fuel (Diener et al., 2014; Ferguson, 2012). In addition, the combined caloric values of local conditioners and that of FS drying outcomes augur well for the technical and the financial viability of using FS as industrial fuel (Bennamoun, 2012).

\section{Local Conditioners for Soil Conditioners}

Closed-loop nutrient cycling is a simple, persuasive and elegant approach to realize efficient natural resource management, improved human well-being and long-term food security. In the spirit of sustainable 
sanitation through recovery of nutrients from FS it is budding step. Normal FS has a carbonnitrogen $(\mathrm{C} / \mathrm{N})$ ratio range of $12-28$. Using $\mathrm{FS}$ as a soil amendment has many benefits over using chemical fertilizers alone (Koyama et al., 2018). Organic matter in FS increase soil water holding capacity, build structure, reduce erosion and provide a source of slowly released nutrients (Katukiza et al., 2012). Furthermore, if FS is co-composted with other organic material such as market wastes, its $\mathrm{C} / \mathrm{N}$ ratio will rise to value of 33 , which means FS has high-quality for agriculture (Jiang at al., 2011).

FS with low solids content should be dewatered prior to composting, either with settling tanks or drying beds. Although composting is a proven technology to produce a safe to use soil amendment, this method faces several challenges. Some of these challenges include: the method is unsuitable for industrial use due to the long time and natural composting modality, aeration is an expensive process and loss of nitrogen due to the insufficient turning of the pile at high temperature (Singh et al., 2017; Chang et al., 2019). Local conditioners that are organic in nature, have potential in addressing the challenges facing faecal sludge co-composting by rising $\mathrm{C} / \mathrm{N}$ ratio of $\mathrm{FS}$ at short time because it contains a significant concentration of phosphates and Total Kjedhal Nitrogen (Odey et al., 2017). It is safe for both plant and human health since it contains antibacterial activity and is non-toxic (Alzohairy et al., 2017). Local conditioners therefore, have the potential for production of soil conditioners instead of a cocomposting method.

\section{Local Conditioners for Bacterial Removal}

FS contains numerous pathogens, most of them are bacteria. These microorganisms are often heterotrophic in nature and thus, rely on a carbon source derived from organic matter as food. Furthermore, the survival or inactivation of pathogens in the FS depends on a number of factors such as temperature, moisture content and competition from indigenous microflora
(Shailemo et al., 2016). Other factors, such as predation, $\mathrm{pH}$, sunlight, oxygen, soil type and texture, also influence the pathogen inactivation. These favourable bacterial survival environments have been disturbed by application of local conditioners in FS. For example, local conditioner through the removing of moisture contents in sludge, methanogenic and acidogenic activity on FS increase and hence, lead to mortality of pathogen organisms (Liu et al., 2012). Also, local conditioners have antibacterial activity on both gram negative and gram-positive bacteria (Al-Awady et al., 2015). For example, according to Ngandjui et al. (2018) Moringa oleifera under a setting of 3 hours reduce Escherichia Coli, faecal coliform and faecal streptococci from faecal sludge leachate by $86.74 \%, 86.3 \%$ and $81.33 \%$, respectively.

\section{Increasing Wastewater and Faecal Sludge Treatment Plant Efficiency}

Local conditioners are known to increase the treatment plant efficiency by decreasing dewatering time and increasing settling of total suspended solids (Katayon et al., 2006). The study conducted by Gold et al. (2016), verify the efficiency of Chitosan to increase settling and dewatering time of sludge treatment plant capacity in Dakar, Senegal. This has multiple benefits including reduction of area of drying beds by $9-26 \%$, application as soil conditioner and application as solid fuel compared with conventional conditioners. Moreover, local conditioners have potentially increased the performance of treatment plant versus capital costs of constructing additional treatment facility if the plant is overloaded (Faye et al., 2017). 


\section{Reducing Treatment Costs}

Locally available conditioners are natural materials obtained within the country and thus, no cost for importation is required (Gold et al., 2016). This assuring its availability whenever needed during the whole process of resources recovery (Niwagaba et al., 2014). As a result, for economic reason, there has been substantial interest in using locally available conditioners in FS conditioning as alternative substances to replace conventional conditioners like Lime $\left[\mathrm{Ca}(\mathrm{OH})_{2}\right]$ in developing countries (Table 2). Rather than that, local conditioners have the ability to improve the quality of dry sludge at low cost and thus, the by-products made by this sludge are easily accessible and are available in market at cheap prices (Seck et al., 2014).

Table 2: Extra cost estimated for different conditioners at Cambérène FS treatment plants (Gold et al., 2016)

\begin{tabular}{|l|l|l|l|}
\hline Availability & Unity & Chitosan & Lime \\
\hline Required dosage & t/year & $1.30-3.25$ & $260-693$ \\
\hline Conditioner dosage & USD/t & 27,500 & 265 \\
\hline \multicolumn{3}{|l|}{ Cost } \\
\hline Treatment cost & USD/day & 171,180 & 171,180 \\
\hline Additional treatment cost & USD/day & $35,750-89,275$ & $68,900-183,64$ \\
\hline Increased treatment cost & $\%$ & $21-52 \%$ & $40-107 \%$ \\
\hline
\end{tabular}

Removal of Heavy Metals, Dyes, Oil and Toxic Salts in the Supernatant of Faecal Sludge

The raw FS contains significant concentration of heavy metals which are not degraded by the processes of sludge treatment (Semiyaga et al., 2017). The sources of these metals in FS arise from different areas, including domestic wastes which are disposed in the toilets. A study conducted by Verrelli et al. (2009) verified that, excessive amount of heavy metal in sludge upsurge the adverse effect on human, plant and environment. Local conditioners guidelines which were provided by $\mathrm{Yu}$ et al. (2011), specified some local conditioners which have the ability to adsorb heavy metal in sludge. Some of the factors which affect the absorption rate of these metals by local conditioners are the dose and the size of conditioners, contact time, agitation speed, temperature, $\mathrm{pH}$ and ionic strength of the aqueous solution (Subramanium et al., 2011). Raji and Anirudhan (1997) reported that, the adsorption rate of heavy metal by local conditioners in the sludge can be $100 \%$ under optimized conditions. Table 3 shows that under optimal conditions sawdust as a local conditioner adsorbed the heavy metal in faecal sludge supernatant at efficiency above $90 \%$. Likewise, Sharma et al. (2006) realized that, these conditioners have the ability of removing heavy metal ions in a wide range of sludge $\mathrm{pH}$ without affecting its strength. For example, Moringa oleifera removes Cadmium in the sludge with a $\mathrm{pH}$ range of 3.5-8 without affecting its strength. Additionally, the study of Lim et al. (2018) designated that some of the local conditioners have the ability to remove dyes, oil, fluoride, aluminium and colour from sludge. 
Table 3: Effect of sawdust concentration on the removal of $\mathrm{Pb}$ (II) and $\mathrm{Cu}$ (II). The initial concentration of lead or copper: $10 \mathrm{mg} / \mathrm{l}, \mathrm{T}=23^{\circ} \mathrm{C}$, contact time: $24 \mathrm{~h}$ (Yu et al., 2011)

\begin{tabular}{|l|l|l|l|l|l|l|}
\hline Sawdust concentration (g/l) & 0 & 5 & 10 & 20 & 30 & 40 \\
\hline \% Removal of Cu (II) & 0 & 78 & 88.7 & 89 & 89.9 & 90 \\
\hline \% Removal Pb & 0 & 98 & 98.3 & 98.4 & 98.5 & 99.3 \\
\hline
\end{tabular}

\section{POTENTIALS FAECAL SLUDGE TREATMENT USING LOCAL CONDITIONERS IN TANZANIA}

\section{Improved Efficiency of Existing Wastewater Treatment Facilities}

In Tanzania, there are inadequate treatment facilities for treating FS while, the few existing ones are overloaded as a result, additional treatment units are required (Brandes et al., 2015). For example, only two of the nine waste stabilization ponds systems are designated to receive FS, while, $90 \%$ of Dar es Salaams inhabitants rely on on-site sanitation technologies which produce FS (Brandes et al., 2015). Additionally, these existing facilities do not function properly since they treat both FS and wastewater while they were designed for wastewater only (Muzaki, 2011). For this reason, it is inevitable to construct new treatment unit in order to meet the desired effluent standard of disposal of FS in environment (Damkjaer et al., 2018). Based on the potential of local conditioners, Tanzania can benefit to treat her FS by using sustainable sources and freely available material in increasing the treatment capacity of existing plants and reduce the capital costs of constructing additional treatment facilities.

\section{Increasing Food Security}

The growth rate of food crop production in Tanzania varies from $0.35 \%$ to $0.88 \%$ (Fraval et al., 2018). This low rate of food production is because of land scarcity and low soil fertility, resulting from the shortening or elimination of the fallow period without concurrent efforts to increase soil nutrients through fertilizer application (Haule et al., 2012). The main approach of the government is to encourage the use of inorganic fertilizer in order to tackle low soil fertility. For example, Tanzania agricultural policy (URT, 2013) strategies for promoting agricultural productivity by increasing nutrients from $8 \mathrm{kgs}$ of fertilizer per hectare to $50 \mathrm{~kg}$ per hectare by 2015 . However, for the large majority of small-scale farmers, such initiatives have had limited effect due to high cost and limited access, which lead to food crisis in most parts of the country due to low food crop production (Haule et al., 2013). Through the potential of local conditioners on production of soil conditioner, Tanzania can increase its soil productivity on a sustainable basis, consequently, raising the income of community and increasing food -healthy security.

\section{Increasing Energy Generation}

Annually, households in urban areas of Tanzania use over one million tonnes of charcoal for cooking. The use of biomass accounts for an average of $90 \%$ of the energy consumption and meets about $40 \%$ to $96 \%$ of cooking needs in urban and rural areas, respectively (Bishoge et al., 2018; Epps and Penick, 2018). The use has a long-term implication on health, climate change, deforestation, environmental degradation and gender dimensions as women and children spend more time on collecting fuel wood (WWF, 2007). Each year charcoal production results in the loss of an estimated 371,728 hectare of forest covers in Tanzania. As the population increases, scientists predict that some 6.91 million hectares of forest will be lost by 2030 , which is equivalent to $8.5 \%$ of Tanzania's total forest cover (Msuya et al., 2011). Other adverse impacts include loss of forest cover which ultimately causes degradation of soil quality by increased soil 
erosion, degradation of water sources and disruption of rainfall pattern including inducing draught (Lambie et al., 2001). Moreover, the poor spend about $35 \%$ of their income on energy expenditure (Elita et al., 2018). The government tried to institute a ban on charcoal production in 2006, but was largely unsuccessful because no alternative source of fuel was provided (Trémolet and Muruka, 2013). Through FS recovery, energy production may be realized which will help to eliminate/reduce energy problems and conserve the environment.

\section{Improving Sanitation Situation}

Poor sanitation in urban slums of Tanzania results in an increase in the prevalence of diseases and pollution of the environment. About 5,800 cases of cholera are reported annually and 18,500 children under the age of 5 years die annually from diarrhoea, with about $90 \%$ of death attributed to poor water, sanitation and hygiene conditions (Mwakitalima et al., 2018). According to a study done by the Water and Sanitation Program of the World Bank (2016), poor sanitation costs the Tanzanian economy TZS 301 billion (USD 206 million) annually. This translates to a loss of $1 \%$ of Tanzania National GDP. Excreta, grey water and solid wastes are the major contributors to the pollution load into the slum environment and pose a risk to public health. The high rates of urbanization and population growth, poor accessibility and lack of legal status in urban slums make it difficult to improve their level of sanitation (URT, 2009). New approaches may help to achieve the sanitation target of the Sustainable Development Goals (SDGs); ensuring environmental sustainability. Resource recovery-oriented technologies minimize health risks and negative environmental impacts. In particular, there has been increasing recognition of the potential of local conditioners for treatment of excreta for energy and soil conditioner recovery as an alternative to solve the sanitation crisis.

\section{Increasing Opportunities for Employment}

Tanzania urban youth unemployment has continued to increase and have remained at extremely high levels, despite the efforts of national governments and international development agencies on promoting sustainable development (Peter, 2013). Based on the NBS (2015) report, in Dar es Salaam urban area, men who are unemployed were $25 \%$, while women were $33.7 \%$. The report explained that, the youth who are unemployed in Dar es Salaam city are $31.5 \%$, while in the other cities are $16.5 \%$ (NBS, 2015). This youth unemployment was made up of first-time job seekers*. Through local conditioner selling, FS collection, production of briquettes and soil conditioners, selling of resource recovery and engaging in agriculture due to the availability of soil productivity opportunities, employment in Tanzania will increase.

\section{CONCLUSIONS}

The findings of this review indicate that there are potentials of local conditioners linked with reducing the cost of operation and maintenance of FS treatment facilities through increasing dewatering rate and efficiency of treatment plants. Also, through reduction of sludge volume in treatment plants, more than $50 \%$ of operating cost is reduced. For this reason, the sanitation issues are solved and the cost of constructing new treatment facilities is avoided. Additionally, these conditioners use to ensure health security through removing and disinfecting pathogens in supernatants of FS and thus, being safe for disposal and reuse. Local conditioners have the potential to solve resource crisis over energy and soil conditioner production. In other words, local conditioners have a potential of contribution to socioeconomic development in Tanzania through renewable energy production, income generation and food- health security, soil and water conservation, eco-sanitation and reduction of environmental degradation. 


\section{ACKNOWLDGEMENT}

Scholarship and research grant support provided by SIDA under the SUSTAIN project to the first author is highly appreciated. Furthermore, we acknowledge technical support provided by the staff of the Department of Water Resources at the University of Dar es Salaam (UDSM) and Lund University Centre for Sustainability Studies (LUCSUS) in Sweden.

\section{REFERENCES}

Abdulazeez Q.M., Jami M.S., Alam. M.Z. and Lwata M. (2015). Analysis of the Efficiency of Sludge Dewatering Using Moringa Oleifera As Natural Phytocoagulant. International Journal of Research in Chemical, Metallurgical and Civil Engg., 2(2): 111-117. http://dx.doi.org/10.15242/IJRCMCE.E12 15032.

Ahmad A.L., Sumathi S. and Hameed B.H. (2006). Coagulation of residue oil and suspended solid in palm oil mill effluent by Chitosan, alum and PAC, 118(1): 99105. https://doi.org/10.1016/j.cej.2006.02.001.

Alloul A., Ganigue R., Spiller M., Meerburg F., Cagnetta C., Rabaey K. and Vlaeminck S.E. (2018). Capture-Ferment-Upgrade: A Three-Step Approach for the Valorization of Sewage Organics as Commodities. Environ. Sci. Technol., 52: 6729 -6742. DOI: 10.1021/acs.est.7b05712.

Alzohairy A.M., Shams R., Abo E.F., Marwa M.A.A. and Ahmed M. (2017). Antimicrobial activity of methanolic extracts of leaves and seeds of three Moringa species grown in Egypt against some human pathogens. Journal of Microbiology, 46: 112-123.

Ashmawy M.A., Moussa M.S., Ghoneim A.K. and Tammam A. (2012). Enhancing the Efficiency of Primary Sedimentation in Wastewater Treatment Plants with the Application of Moringa Oleifera Seeds and Quicklime. Journal of American Science, 2(8): 494-502.

Bennamoun L. (2012). Solar drying of wastewater sludge: A review. Renewable and Sustainable Energy Reviews, 16: 1061-1073. doi: 10.1016/j.rser.2011.10.005

Biggs S. (2007). Polymeric flocculants. Encyclopedia of surface and colloid science. Taylor and Francis, New York, 2nd edn., 4973-4989.

Bishoge O.K., Zhang L., Mushi W.G. and Suntu S.L. (2018). The overview of the legal and institutional framework for the oil and natural gas sector in Tanzania. A review. Journal of applied and Advanced Research, 3(1): 1-16. DOI: 10.21839/jaar.2018.v1i1.127

Brandes K., Schoebitz L., Kimwaga R. and Strande L. (2015). SFD Promotion Initiative, Dar es Salaam, Tanzania. Eawag/Sandec The Department of Sanitation, Water and Solid Waste for Development (Sandec) at the Swiss Federal Institute of Aquatic Science and Technology (Eawag), Switzerland.

Byrne A., Gold M., Turyasiima D., Getkate W., Niwagaba C., Babu M., Maiteki J., Orwiny M. and Strande L. (2015). Suitable bio-wastes for energy recovery. Sludge to energy Enterprises in Kampala (SEEK), Project, EAWAG Aquatic Research and Sandec, Dübendorf, Switzerland.

Cofie O., Agbottah S., Strauss M., Esseku H., Montangero A., Awuah E. and Koné D. (2006). Solid-liquid separation of faecal sludge using drying beds in Ghana: implications for nutrient recycling in urban agriculture. Water Research, 40(1): 75-82. DOI: 10.1016/j.watres.2005.10.023

Cross P. and Coombes Y. (Eds.) (2014). Sanitation and Hygiene in Africa: Where Do We Stand? Analysis of the AfricaSan Conference, Kigali, Rwanda. IWA Publishing, London, UK.

Cockx L., Colen L., De Weerdt J., Gomez Y. and Paloma S. (2019), Urbanization as a driver of changing food demand in Africa: Evidence from rural-urban migration in Tanzania, EUR 28756 EN, Publications Office of the European Union, Luxembourg, doi:10.2760/515064, JRC107918. 
Chase C. and Hutton G. (2016). The Knowledge Base for Achieving the Sustainable Development Goal Targets on Water Supply, Sanitation and Hygiene. Int. J. Environ. Res. Public Health, 13(6): 536 Doi: 10.3390/ijerph13060536.

Chang R., Li Y., Qing C., Qiuyue G. and Juntao J. (2019). Comparing the effects of three in situ methods on nitrogen loss control, temperature dynamics and maturity during composting of agricultural wastes with a stage of temperatures over $70^{\circ} \mathrm{C}$. Journal of Environmental Management, 230: 119-127. https://doi.org/10.1016/j.jenvman.2018.09. 076.

Chony S.Y., Prasad K.M.N., Wu T.Y. and Ramanan R.N. (2015). A review on common vegetables and Legumes as promising plant-based Natural coagulants in water clarification. Inc. Environ. Sci. Techno., 12: 367-390. DOI 10.1007/s 13762-013-0446-2.

Damkjaer K., Weisser J.J., Mikala S.C., Mdegela R. and Jarne S.B. (2018). Occurrence removal and risk assessment of steroid hormones in two wastewater stabilization pond systems in Morogoro, Tanzania, Chemosphere, (212): 11421154.

https://doi.org/10.1016/j.chemosphere.201 8.08.053.

Ding A., Fangshu Q., Heng L., Shaodong G., Yuhui R., Guoren X. and Guibai L. (2014). Effect of adding wood chips on sewage sludge dewatering in a pilot-scale plateand-frame filter press process. RSC. Advances. DOI: 10.1039/c4ra03584d

Diener S., Semiyaga S. and Niwagaba C.B. (2014). A value proposition: Resource recovery from faecal sludge - Can it be the driver for improved sanitation?. Resour Conserv Recycl., 88: 32-38. https://doi.org/10.1016/j.resconrec.2014.04 .005 .

Dodane P.H., Mbéguéré M., Sow O. and Strande L. (2012). Capital and operating costs of full- scale faecal sludge management and wastewater treatment systems, in Dakar, Senegal. Environmental
Science and Technology, 46(7): 37053711. DOI: 10.1021/es2045234.

El-Awady M.A., Hassan M.M., Abdel-Hameed E.S. and Gaber A. (2015). Comparison of the antimicrobial activities of the leavescrude extracts of Moringa peregrina and Moringa oleifera in Saudi Arabia. Int. J. Curr. Microbiol. App. Sci., 4(12): 1-9.

Elita R.W., Guangnan C., Les B. and Catherine $H$ (2018). Gasification of non-woody biomass: A literature review. Renewable and Sustainable Energy Reviews, 89: 184193

https://doi.org/10.1016/j.rser.2018.03.023.

Epps M.J. and Penick C.A. (2018). Facultative mushroom feeding by common woodland ants (Formicidae, Aphaenogaster spp.), Food Webs, 14: 9-13, https://doi.org/10.1016/j.fooweb.2017.12.0 $\underline{01}$

Faye M.C.A.S., Zhang Y. and Yang J. (2017). Extracellular polymeric substances and sludge, solid/liquid separation under Moringa Oleifera and Chitosan conditioning: a review. Environmental Technology Reviews, 6(1): 59-73. https://doi.org/10.1080/21622515.2017.12 82544.

Ferguson H. (2012). Briquette businesses in Uganda. The potential for briquette enterprises to address the sustainability of the Ugandan biomass fuel market. GVEP International, London, U.K.

Fraval S., James H., Mats L., Simon J.O., George S., Nils T., Silvia S., Mario H., Mark T.V.W. (2018). Livelihoods and food security in an urban linked, high potential region of Tanzania: Changes over a three year period, Agricultural Systems, 160: 87-95. https://doi.org/10.1016/j.agsy.2017.10.013

Gold M., Dayer P., Faye M.C., Clair G, Seck A., Niang S., Morgenroth E. and Strande L. (2016). Locally produced natural conditioners for dewatering of faecal sludge. Environ. Technol., 37(21): 28022814.

doi:

10.1080/09593330.2016.1165293.

Gold M., Niang S., Niwagaba C. B., Eder G., Muspratt A.M. and Diop P.S. (2014). 
Results from FaME (Faecal Management Enterprises) - can dried faecal sludge fuel the sanitation service chain?. 37th WEDC International Conference, Hanoi, Vietnam.

Hanghighi H., Bird S., Big F., Leo R.D., Bedin E., Pfeifer F., Siesler H.W., Licciardello F. and Pulvirent A. (2019). Comprehensive characterization of active chitosan gelatin blend films enriched with different essential oils. Food Hydrocolloids, 95: 3342.

https://doi.org/10.1016/j.foodhyd.2019.04. 019.

Haule C.B.M., Mlozi M.R.S. and Mulengera M.K. (2013). Land degradation and smallholder farmer's response. A case of villages in the Southern Parts of Ludewa District, Iringa Region. Tanzania Journal of Agricultural Sciences, 12(1): 11-21.

Jiang T., Schuchard F., Li G., Guo R. and Zhao Y. (2011). Effect of $\mathrm{C} / \mathrm{N}$ ratio, aeration rate and moisture content on ammonia and greenhouse gas emission during the composting. Journal of Environmental Sciences, 23(10): 1754-1760. https://doi.org/10.1016/S1001-

0742(10)60591-8.

Jin B., Wilén B.M. and Lant P. (2004). Impacts of morphological, physical and chemical properties of sludge flocs on dewaterability of activated sludge. Chemical Engineering Journal, 98: 115126. DOI: $10.1016 /$ j.cej.2003.05.002

Kansal S.K. and Kumari A. (2014). The potential of $M$. oleifera for the Treatment of Water and Wastewater. Chem. Rev., 114(9): $\quad 4993-5010 . \quad$ DOI: $10.1021 / \mathrm{cr} 400093 \mathrm{w}$

Katayon S., Noor M.J., Asma M., Ghani L.A., Thamer A.M., Azni I., Ahmad J., Khor B.C. and Suleyman A.M. (2006) . Effects of storage conditions of Moringa Oleifera seeds on its performance in coagulation, Bioresour. Technol., 97: 1455-1460. DOI: 10.1016/j.biortech.2005.07.031

Katukiza A.Y., Ronteltap M., Niwagaba C.B., Foppen J.W.A., Kansiime F., Lens P.N. (2012). Sustainable sanitation technology options for urban slums. Biotechnology Advances, 30(5): 964-978. doi: 10.1016/j.biotechadv.2012.02.007.

Kolecka K., Gajewska M., Pempkowiak H.O. and Rohde D. (2017). Integrated dewatering and stabilization system as an environmentally friendly technology in sewage sludge management in Poland, Ecological Engineering, 98: 346-353. http://dx.doi..org/10.1016/j.ecoleng.2016.0 8.011

Koyama M., Nagao N., Syukri F., Rahim A.A., Kamarudin S.M., Toda T; Mitsuhashi T. and Nakasaki K. (2018). Effect of temperature on thermophilic composting of aquaculture sludge: $\mathrm{NH} 3$ recovery, nitrogen mass balance, and microbial community dynamics, Bioresource Technology, 265: 207-213. https://doi.org/10.1016/j.biortech.2018.05. 109

Lambin E.F., Turner B.L., Geist H.J., Agbola S.B., Angelsen A., Bruce J.W., Coomes O.T., Dirzo R., Fischer G. and Folke C. (2001). The causes of land use and landcover change: Moving beyond the myths, Global Environmental Change, 11(4): 261269. https://doi.org/10.1016/S09593780(01)00007-3

Lim W.L.K., Chung E.C.X., Chong C.H., Ong N.T.K., Hew W.S., Kahar N.B. and Goh Z.J. (2018). Removal of fluoride and aluminium using plant-based coagulants wrapped with fibrous thin film. Process Safety and Environmental Protection, 117: 704-710. https://doi.org/10.1016/j.psep.2018.06.018.

Lim J.S., Manan Z.A., Alwi S.R.W. and Hashim H. (2012). A review on utilization of biomass from rice industry as a source of renewable energy. Renewable and Sustainable Energy Reviews, 16(5): 30843094. https://doi.org/10.1016/j.rser.2012.02.051.

Liao Y., Zheng H. and Qian L. (2014). UVInitiated polymerization of hydrophobically associating cationic polyacrylamide modified by a surface active monomer. Ind. Eng Chem Res., (53): 11193-11203. https://doi.org/10.1021/ie5016987

Liu S., Hu M., Zeng T., Wu R., Jiang R., Wei 
J., Wang L., Kong J. and Chen Y. (2012). Lateral Dimension dependent antibacterial activity of Graphene oxide sheets. ASC. Nano., 28: 12364-12372. doi: 10.1021/la3023908.

Luo H., Ning X. and Liang X. (2013). Effects of sawdust-CPAM on textile dyeing sludge dewaterability and filter cake properties. Bioresour Technol., 139: 330-336. doi: 10.1016/j.biortech.2013.04.035.

Mittal A., Mittal J., Malviya A., Kaur D. and Gupta V. (2010). Decoloration treatment of a hazardous triarylmethane dye, Light Green SF (Yellowish) by waste material adsorbents. J. Colloid Interface Sci., 342: 518-527. doi: 10.1016/j.jcis.2009.10.046.

Mukhopadhyay P., Maity S., Mandal S Chakraborti A.S., Prajapati A.K. and Kundu P.P. (2018). Preparation, characterization and in vivo evaluation of $\mathrm{pH}$-sensitive, safe quercetin-succinylated Chitosan-alginate core-shell-corona nonparticle for diabetes treatment. Carbohydrate Polymers, 182: 42-51. doi: 10.1016/j.carbpol.2017.10.098

Muspratt A.M., Nakato T., Niwagaba C., Dione H., Kang J., Stupin L., Regulinski J. and Strande L. (2014). Fuel potential of faecal sludge: calorific value results from Uganda, Ghana and Senegal. Journal of Water, Sanitation and Hygiene for Development, 4(2): 223-230. https://doi.org/10.2166/washdev.2013.055

Muzaki S. (2011). East Africa Practitioners Workshop on Pro Poor Urban Sanitation and Hygiene LAICO Umubano Hotel, Kigali, Rwanda, March 29th-31. Irc.Nl., 84 (March), 29. Retrieved from http://www.irc.nl/content/download/16238 2/590902/file/11. Children as effective change agents.pdf.

Mwakitalima A., Massa K., Seleman A. and Kassile T. (2018). Scaling up rural sanitation in Tanzania: evidence from the National Sanitation Campaign. Journal of Water, Sanitation and Hygiene for Development, 8(2): 290-306. https://doi.org/10.2166/washdev.2018.072.

Msuya N., Masanja E. and Abrahamu K.T. (2011). Environmental Burden of Charcoal
Production and Use in Dar es Salaam, Tanzania. Journal of Environmental Protection, 2: 1364-1369. Doi:10.4236/jep.2011.210158.

Ndabigengesere A., Narasia K.B. and Talbot B.G. (1995). Active agents and mechanisms of coagulation of turbid waters using Moringa oleifera, Water Research, 29: 703-710. https://doi.org/10.1016/00431354(94)00161-Y

Ngandjui T.Y.A., Djumyom W.G.V., Wanda C., Soh K.E., Kengne I.M. and Kouam F.S. (2018). Use of Moringa Oleifera seed extracts to polish effluents from natural systems treating faecal sludge. Environmental Technology, 1: 1-13. DOI: 10.1080/09593330.2018.1435736

Niwagaba C.B., Mbéguéré M. and Strande L. (2014). Faecal sludge quantification, characterization and treatment objectives. In: London IWA, 19-44.

Odey E.A., Li. Z., Zhou X. and Kalakodio L. (2017). Faecal sludge management in developing urban centers: a review of the collection, treatment, and composting. Environmental Science and Pollution Research, 2(30): 23441-23452. doi: 10.1007/s11356-017-0151-7

Padla E.P., Solis L.T., Levida R.M., Shen C.C. and Ragasa C.Y. (2012). Antimicrobial Isothiocyanates from the Seeds of Moringa oleifera Lam. Z. Naturforsch. C. 2012;67:557-564. doi: 10.5560/ZNC.2012.67c0557.

Peter S. (2013). Nature Of Urban youth unemployment in Tanzania: Challenges and consequences. REPOA'S 19th Annual Research Workshop.

Qi Y., Khagendra B., Thapa A. and Hoadley F.A. (2019). Application of filtration aids for improving sludge dewatering properties - A review. Chemical Engineering Journal, 171(2): 373-384. DOI: 10.1016/j.cej.2011.04.060

Raji C. and Anirudha T.S. (1997). Chromium (VI) adsorption by sawdust carbon: Kinetics and equilibrium, NISCAIRCSIR., India, 04(5): 228-236. http://hdl.handle.net/123456789/30928. 
Seck A., Gold M., Niang S., Mbéguéré M., Diop C. and Strande L. (2014). Faecal sludge drying beds: increasing drying rates for fuel resource recovery in Sub-Saharan Africa. Journal of Water, Sanitation and Hygiene for Development, 5(1): 72-80. https://doi.org/10.2166/washdev.2014.213.

Semiyaga S., Okure M.A.E., Niwagaba C.B., Nyenje P.M. and Kansiime F. (2017). Dewatering as a Critical step in Urban Slum-Based Faecal Sludge Management, International Journal of Environmental Science and Technology, 14 (1): 151-164. DOI 10.1007/s13762-016-1134-9

Sharma P., Pushpa K.M.M. and Srivastava S.S. (2006). Ternary bio sorption studies of $\mathrm{Cd}$ (II), Cr (III) and Ni (II) on shelled Moringa oleifera seeds. Bioresource Technology, 98(2): 474-477. DOI: 10.1016/j.biortech.2005.12.016016.

Shailemo D.H.P., Kwaambwa H.M., KandawaSchulz M. and Msagati T.A.M. (2016): Antibacterial activity of Moringa ovalifolia and Moringa oleifera methanol, n-hexane and water seeds and bark extracts against pathogens that are implicated in waterborne diseases. Green and Sustainable Chemistry, 6: 71-77. DOI: 10.4236/gsc.2016.62006.

Shikun C., Lei Z., Mingyue Z., Xue B., Zifu L. and Mang H.P. (2017). Assessment of two faecal sludge treatment plants in urban areas: A Case study in Beijing. Int J Agric and Biol Eng., 10(3): 237-247.

Singh S., Mohan R.R., Rathi S. and Raju J.N. (2017). Technology options for faecal sludge management in Riya developing countries: benefits and revenue from reuse. Environmental Technology and Innovation, 7: 203-218. DOI: 10.1016/j.eti.2017.02.004

Subramanium S., Nand V., Maata M. and Koshy K. (2011). Moringa Oleifera and other local seeds in water purification in developing countries. Res J Chem Environ 15 (2): 135-138.

Trémolet S. and Muruka G. (2013). Evaluating the potential of microfinance for sanitation in Tanzania, 1-60.

URT - United Republic of Tanzania (2009).
Water Supply and Sanitation in Tanzania: Turning Finance into Services for 2015 and Beyond. An AMCOW Country Status Overview, 1-36.

URT - United Republic of Tanzania (2013). National Agriculture Policy, Ministry of Agriculture Food Security and Cooperatives, Dar es Salaam.

National Bureau of Statistics (NBS) Tanzania (2015). Tanzania Integrated Labour Force Survey: Analytical Report 2014, National Bureau of Statistics; The World Bank; UNICEF; DFID; International Labour Organization (ILO); Foreign Affairs, Trade and Development, Canada, United Republic of Tanzania, Dar es Salaam.

Verrelli D.I., Dixon D.R. and Scales P.J. (2009). Effect of coagulation conditions on the dewatering properties of sludges produced in drinking water treatment. Colloids and Surfaces A: Physicochemical and Engineering Aspects, 348(1-3): 1423.

https://doi.org/10.1016/j.colsurfa.2009.06. 013

WWF (2007). A Project Proposal to Begin Resolving the Environmental Crisis Caused by Charcoal the Dar Charcoal Project, Ministry of Natural Resources Tanzania.

Wang S. and Viraraghavan T. (1997). Wastewater sludge conditioning by fly ash. Waste Management, 17(7): 443-450. https://doi.org/10.1016/S0956053X(97)10050-2

Wang J., Yuan S., Wang Y., Yu H., (2013). Synthesis, Characterization and Application of a Novel Starch-based Flocculant with High Flocculation and Dewatering Properties. Water Research, 47(8): 2643-2648. doi: 10.1016/j.watres.2013.01.050.

World Health Organization (WHO) and United Nations Children's Fund (UNICEF) (2017). Progress on Sanitation and Drinking Water, Geneva, Switzerland.

World Bank (2016). World Development Indicators. Available online at http://data.worldbank.org/datacatalog/world-development-indicators. 
Retrieved on 7th March 2019.

Yin C.Y. (2010). Emerging usage of plantbased coagulants for water and wastewater treatment. Process Biochemistry, 45: 14371444. DOI: $10.1016 /$ j.procbio.2010.05.030

Yongabi K.A. (2004). Studies on the use of Medicinal Plants and Macro fungi (lower plants) in water and wastewater purification. Proceeding of an E-Seminar organized by the International organization for biotechnology and Bioengineering, 24: $1-14$.

Yongabi K.A. (2010). Biocoagulants for Water and Waste Water Purification: a Review. International Review of Chemical Engineering, 2(3):1-15.

Yu B., Zhang Y., Shukla S.S. and Dorris K. L. (2011). The removal of heavy metals from aqueous solutions by sawdust adsorption removal of lead and comparison of its adsorption with copper. Journal of Hazardous Materials., 84 (1): 83-94. DOI: 10.1016/s0304-3894(01)00198-4

Zhang X., Khang H., Zhang Q., Hao X., Hun X., Zhang W. and Jiao T. (2019a). The porous structure effects of skeleton builders in sustainable Sludge dewatering process. Journal of Enviromental Management, 230: 14-30. https://doi.org/10.1016/j.jenVman 2018.09.049.

Yuan H., Zhu N. and Song F. (2011). Dewaterability characteristics of sludge conditioned with surfactants pretreatment by electrolysis. Bioresource Technology., 102(3): 2308-2315. DOI: 10.1016/j.biortech.2010.10.065

Zhang J., Hu Q. and Lin S. (2019b). Study on the efeect of chitosan condition sludge dewatering. Water Science and Technology, $\quad$ 79(3): 501-509. https://doi.org/10.2166/wt.2019.073.

Zhai L.F., Sun M. and Song W. (2012). An integrated approach to optimizing the conditioning chemicals for enhanced sludge conditioning in a pilot-scale sludge dewatering process. Bioresour Technol., 21: 161-168. DOI: 10.1016/j.biortech.2012.06.093 